Н. В. Романова

\title{
СЕМАНТИКА АСОЦІАТІВ НА СЛОВО-СТИМУЛ ÜBERRASCHUNG (НА МАТЕРІАЛІ СПРЯМОВАНОГО АСОЦІАТИВНОГО ЕКСПЕРИМЕНТУ)
}

Романова Н. В. Семантика асоціатів на слово-стимул Überraschung (на матеріалі спрямованого асоціативного експерименту).

У статті розкрито семантичне наповнення асоціатів на німецькомовне словостимул Überraschung подив, отриманих у ході спрямованого асоціативного експерименту. Визначено домінантні значення аналізованого слова як ядерної основи. Доведено, що семантика асоціата як лінгвістичного явища окреслена формулою «образ і мовний рівень».

Ключові слова: семантика, асоціати, слово-стимул, асоціації, реакції, стереотип, індивідуально-авторське значення.

Романова Н. В. Семантика ассоциатов на слово-стимул Überraschung (на материале направленного ассоциативного эксперимента).

В статье раскрыто семантическое наполнение ассоциатов на немецкоязычное слово-стимул Überraschung удивление, полученных в ходе направленного ассоциативного эксперимента. Определены доминантные значения рассматриваемого слова как ядерной основы. Доказано, что семантика ассоциатов как лингвистического явления очерчена формулой «образ и языковой уровень».

Ключевые слова: семантика, ассоциаты, слово-стимул, ассоциации, реакции, стереотип, индивидуально-авторское значение. 
Romanova N. V. Semantics associates on the word-stimulus Überraschung (based on directional associative experiment).

The article deals with the semantic content of the associates on German-wordstimulus Überraschung surprise is obtained by directional associative experiment. The dominating importance of the test words as a nuclear base. Proved, that the semantics associates as linguistic phenomenon outlined formula «image and language level».

Key words: semantics, associates, word-stimulus, associations, reactions, stereotype, individual-authorsemantics.

Проблема семантики асоиіатів виникає, мабуть, разом із зародженням думки про природу мовної свідомості, різнорідність і багатогранність зв'язків внутрішнього світу людини, котра локалізована й мешкає в освоєному й присвоєному нею предметному, багатоликому й множинному зовнішньому світі. У цьому контексті кожний одержаний асоціат є самоцінністю, оскільки його семантика існує mуm і тепер. Вона скорочує дистанцію між запланованою або змодельованою комунікативною ситуацією і ситуацією реальною, несе

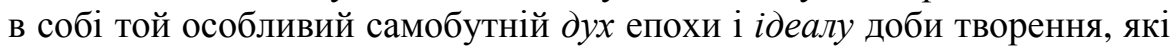
характерні для «всіх зафіксованих контекстів вживання слова» і / чи комплексу «психолінгвістичних експериментів зі словом» [10, с. 77].

Вважається, що зв'язок між значенням лексико-семантичної одиниці та іiі контекстом (власне мовним і ситуативним) «проявляється передусім у різній сполучуваності - семантичній і граматичній - різних значень багатозначного слова» [11, с. 161-162]. Тобто для виявлення семантики асоціатів необхідно враховувати взаємозв'язок і взаємозалежність між чотирма основними чинниками - контекстом, сполучуваністю, окресленою ситуацією й значенням полісеманта. На наш погляд, така «кооперативна взаємодія» не може повною мірою вирішити проблему семантики асоціату, адже стратегія будь-якої комунікації $\epsilon$ «завжди усвідомленим й осмисленим планом дій» [8, с. 197]. Крім того, навіть за умови контролю дій підсвідомі механізми будуть також «спрацьовувати».

Таким чином, семантика асоціату в іiі повному обсязі (від постановки мети до комунікативного ефекту) буде містити в собі фреймову структуру, що впорядковує, організовує основну, типову й потенційно можливу інформацію, що асоційована 3 тим чи іншим концептом [6, с. 7].

Формування концепту - це складний процес редукції результатів досвідного пізнання дійсності до меж людської пам’яті й співвідношення їx із уже засвоєною комунікативно значущою для (аутентичних) носіїв мови інформацією. Отож зміст концепту $\epsilon$ ширшим i від лексикографічного, i від психологічно реального 
значення [9, с. 291]. Останнє можна реконструювати, як уже зазначалося, за допомогою методу асоціативного експерименту. Можливі вільні й спрямовані асоціативні експерименти (далі САЕ). Про значення і цінність САЕ йтиметься нижче.

Метою пропонованої студії є виявлення психологічно реального значення слова-стимулу Überraschung подив.

Для досягнення поставленої мети необхідно вирішити такі завдання: 1) коротко охарактеризувати переваги й недоліки САE; 2) визначити формально граматичні особливості одержаних асоціатів на слово-стимул Überraschung у перебігу CAE; 3) окреслити семантичне наповнення словастимулу відповідно.

Об'єктом дослідження постають одержані асоціати на словостимул Überraschung у перебігу САЕ, предметом вивчення лінгвістичні й семантичні характеристики одержаних асоціатів.

Розглянемо більш детально особливості й специфіку САЕ.

Стратегія САЕ націлена на звуження зони асоціативного пошуку, обмеження синтагматичних асоціацій і посилення орієнтації на парадигматичні відповідно. При цьому актуальність зв'язку словастимулу і реакції на нього змінюється, на передній край висуваються ті асоціати, що перебували на периферії асоціативних структур у перебігу вільного асоціативного експерименту. Можна стверджувати, що саме САЕ впливає на квантитативно-квалітативну конфігурацію семантичного простору слова-стимулу.

У семантичному просторі асоціатів, стверджують Л. В. Засєкіна й С. В. Засєкін, репрезентовано не лише характеристики об'єктів, а й ставлення індивіда до них [2, с. 80]. Тому слід зважити також на той факт, що одержані асоціати $\epsilon$ результат граничного оціночносуб'єктивно-об'єктивного «запиту» пам'яті респондентів про досліджуваний об' єкт і його зв'язки з групою об'єктів саме в перебігу $C A E$. У цій граничності приховано динамізм, змінність, трансформація семантичного простору асоціацій. Якщо змінити деякі умови CAE, скажімо, тривалість, місцезнаходження, температурний режим чи санітарні вимоги і т.ін., то якісні й кількісні показники асоціацій можуть бути діаметрально протилежними. Отже, САЕ примушує досліджуваних активізувати саме периферійну асоціативну зону, «миттєво» і без вагань вибрати й вербалізувати стереотипний чи індивідуальний асоціат у рамках не лише індивідуального, а й історично-культурного досвіду.

Семантика асоціата - це семантика-репродукція, що 
детермінована штучно однією із вірогідних (експериментально) мовних і предметних ситуацій, за якої досліджувані перетворюються із «пасивних» носіїв знань про об'єкт і ставлення до нього в «активних» користувачів i інтерпретаторів цих знань. Формально схематичне відношення між носієм і користувачем знань можна зобразити таким чином: досліджувані (на початку САЕ) як «резервуар, вмістилище, архів інформації» $\rightarrow$ CAE як «медіатор» між «пасивним» і «активним» $\rightarrow$ досліджувані (в кінці САЕ) як «декодувач, стратег, інтерпретатор». Асоціативні процеси грунтуються на автоматизмі, виробленому системою тимчасових нервових зв' язків [4, с. 105].

Перевага будь-якого експерименту i, в тому числі САE, полягає в тому, що дослідник сам викликає явища, що його цікавлять, а не чекає ïх появи. Тобто $є$ можливість змоделювати умови для прояву психологічної діяльності протягом певного часу, безпосередньо спостерігати за іiї перебігом, спланувати бажану й необхідну кількість матеріалу щодо досліджуваного предмета, систематично й цілеспрямовано використовувати одержані результати для практичної діяльності тощо. Недоліком цього методу є те, що на об'єктивність одержаної інформації істотно впливає, 3 одного боку, наявність чи відсутність установки в досліджуваного на щирість у відповідяхреакціях, з іншого - здатність респондентів об'єктивно оцінювати зміст слів-стимулів і реагувати на них згідно завдання - першою асоціацією, що спаде їм на думку. Acoųiaųiя (від лат. associatio - з’єднання) грунтується на такому типі зв'язку «між психічними явищами, при якому актуалізація одного з них викликає актуалізацію іншого» [2, с. 54]. Це зв'язок, що здатний поєднувати існуючий досвід індивіда 3 новим його досвідом, призводити до активації стереотипів, змін оцінок, структурації чи переструктурації певних сегментів концептуальної й мовної картин світу, формування нових стереотипів, появи нових системоутворювальних зв'язків. Отже, важливою закономірністю розглядуваного зв'язку є його вибірковість, яка виявляється в тому, що індивід поєднує явища й предмети об'єктивного чи віртуального світу не довільно, а за їхніми окремими ознаками, властивостями, характеристиками чи рисами. Швидкість вибору асоціацій у різних людей різна, бо залежить від типу нервової системи організму, знань людини про об'єкти, сформованості «банку образів» об' єктів, вікового цензу, мотивації, ситуації переживання, емоційного забарвлення останнього (негативне, позитивне, нейтральне), рівня володіння мовою і мовленнєвої реакції тощо. Ми свідомі того, що досліджуванні, уявляючи кожне слово-стимул, звичайно, залишать поза увагою 
варіативність деяких ознак об' єкта. Проте, якщо абстрагуватися від цих варіацій, самий факт одержання асоціативного поля підвищує міру системності психологічно реального значення Überraschung.

Аудиторія нашого САЕ - це аутентичні носії мови у віці від 15 до 69 років, котрі мешкають у різних куточках Німеччини - всього 80 осіб: 50 жінок і 30 чоловіків. Жіноча домінантність визначається передусім специфікою майбутньої професії, активнішою життєвою позицією, емоційною зрілістю, комунікабельністю.

Форма проведення САЕ - 1) макрогрупова (Дрезден, Дюссельдорф, Майнц, Мюнхен - від 20 до 8 осіб), 2) мікрогрупова (Вупперталь, Галле, Кіль - від 5 до 3 осіб), 3) індивідуальна (від 1 до 2 осіб).

Рід занять респондентів варіює: учениці й учні (3), студентки й студенти педагогічних і філологічних факультетів університетів м. Майнц (26), Мюнхен (24), спеціалісти у різних галузях виробництва: a) технічній (8), б) медичній (5), в) соціальній (4), г) економічній (3), г) юридичній (3), д) обслуговування (4).

Форма подачі слів-стимулів і викладення відповідей-реакцій письмова. Термін проведення САЕ - лютий-березень 2012 р.

Було пред’явлено подразники у вигляді 25 слів-стимулів (усього п'ять кластерів). При цьому Überraschung інвентаризовано в IV кластері «Фундаментальні позитивні емоції» (імпліцитно через чистоту САE).

Нами зареєстровано 79 чи 98,75\% асоціатів i 1 чи $1,25 \%$ ігнорування. Ігнорування може свідчити про відсутність знань щодо предмету дослідження чи упереджене ставлення, «антипатію» досліджуваного до САЕ загалом, чи слова-стимулу зокрема, специфіку «генетичної» i / чи «культурної» пам'яті, в якій стерлися чи забулися певні коди, пов'язані 3 первісним поняттям Überraschung, дистанціюванням асоціацій від ядерної зони асоціативних структур тощо.

Аналіз відповідей-реакцій, вироблений в психології й психолінгвістиці, охоплює три напрями: лінгвістичний, психолінгвістичний i психологічний [5, с. 93], два принципи формальний і змістовий. Зрозуміло, що лінгвістична характеристика включає аналіз сказаного й вираженого мовою, психолінгвістична характеристика - сказаного й вираженого мовною особистістю, психологічна характеристика - сказаного й вираженого в дійсності [2, с. 108-109]. У цьому контексті асоціат убачається як трихотомія «ідеальне - матеріально-ідеальне - матеріальне».

3 огляду на формальний аналіз, розглядаються фонетичні, 
словотвірні [7, с. 109] і граматичні асоціації [5, с. 93]; змістовий аналіз це виділення парадигматичних, синтагматичних і / чи тематичних типів відношень між стимулом і реакцією [7, с. 109]. Отже, семантика асоціата як лінгвістичного явища буде окреслена формулою «образ i мовний рівень», семантика асоціата як психолінгвістичного явища формулою «гештальт і словесний образ», семантика асоціата як психологічного явища - формулою «гештальт і оцінка».

Для лінгвістичного аналізу одержаних асоціатів виходитимемо iз формально граматичного рівня. Реєстр асоціатів подається в алфавітному порядку. Було виокремлено такі основні різновиди реакцій:

1) реакції-словоформи (f = 71 чи 88,75\%): Ei, Erschrecken, Erstaunen, Freude (25), Freunde (2), Freundin, Geburtstag, Geburtstagsfeiern, Geburtstagsgeschenk, Geschenk (18), Geschenke, Gesichtsausdruck, Heimlichkeit, Innerhofftes, Kind, Kinderfreude, Lachen, Neuigkeit, Party (2), Schach, Schmerzhaftes, Schreck, Schwangerschaft, Stress, Süßigkeit, Traum, Verachtung, Welt, Wirrwarr;

2) реакції-словосполучення ( $\mathrm{f}=3$ чи 3,75\%): bunt, interessant, glücklich sein;

3) реакції-синтагми ( $\mathrm{f}=2$ чи 2,5\%): große Augen, mag nicht;

4) реакції-ланцюг слів ( $\mathrm{f}=2$ чи 2,5\%): Kinder, Blumen; Überraschungseier Kinderschokolade;

5) реакції-власні назви ( $\mathrm{f}=1$ чи $1,25 \%$ ): Paris.

Найпоширенішими реакціями $€$ реакції-словоформи, що може свідчити про той факт, що слова існують у фонді мовної пам'яті як віртуальні, номінативні мовні одиниці, що активізують конкретні (Ei) (31 чи 38,75\%), абстрактні (Freude (25) (36 чи 45\%) й збірні поняття (Schmerzhaftes) (1 чи 1,25\%), кamezopï: «материнство» (Schwangerschaft), «світ» (Welt), «свято» (Geburtstag), «смак» (Süßigkeit), «столиця» (Paris), «емоції» (Stress) (усього 11 чи 13,75\%), уявлення про інтенсивність структури космічної субстанції (Wirrwarr) (1,25\%). Отже, поняття, категорії й уявлення є мірою асоціатів на слово-стимул Überraschung. Узагальнено, їх співвідношення $є$ прямо пропорційним: що більше понять, то менше категорій, що більше категорій, то менше уявлень. Безумовної протилежності між ними не існує.

За своєю суттю поняття - це збереження істотних ознак об’єктів, категорія - це збереження певного інваріанта ознак об'єктів, уява - це відтворення збережених істотних ознак і / чи інваріантної ознаки і витвір нового образу об' єктів. I збереження, і відтворення, і творення $є$ акт розуму. Варто зважити й на те, що ключовими компонентами розуміння будь-яких 
фактів є достатні знання та життєвий досвід людини: зміст одержаних асоціатів корелюватиме 3 глибиною знань i емоційним досвідом досліджуваних, їхнім умінням цілеспрямовано інтерпретувати фрагменти об' єктивного світу.

До основних граматичних характеристик наведених слів належать: 1) загальне функціональне навантаження мовних одиниць слово (75 чи 93,75\%), наприклад, bunt, і словосполучення (2 чи 2,5\%), наприклад, glücklich sein; 2) гомогенний характер лексико-граматичного класу слів - повнозначні частини мови, зокрема: іменники (71 чи $88,75 \%)$, прикметники (2 чи 2,5\%), дієслова (2 чи 2,5\%); 3) особливість письмової форми викладення асоціатів - іменники подаються без артикля, наприклад: Schmerzhaftes, тобто акцентується суто значення, а не граматичні категорії слова; прикметники - у позитивній формі, одним різновидом - якісні, наприклад: interessant; дієслова постають як копулятивні мовні одиниці, наприклад: glücklich sein, i модальні, наприклад: $\boldsymbol{m a g}$ nicht; 4) категорія числа - однина, наприклад: Kind i множина, наприклад: Kinder, Blumen; 5) функція слова у висловлюванні чи реченні - прикметники як предикатив, наприклад: glücklich sein; 6) засіб утворення «словника-асоціатів» досліджуваних - словотворення (Schmerzhaftes), зміна значення слова (Verachtung), запозичення (англ. Stress, лат. Feier, interessant, снідер. Schach, фp. Party (2); 7) тип словотворення слів «словника» - прості (Ei), похідні (Lachen), складні (Kinderfreude); 8) спосіб словотворення: а) суфіксальний (Süßigkeit), б) префіксальний (Erstaunen), в) конверсивний [дієслова] (Erschrecken), г) словоскладання (Geburtstagsfeier); 9) походження мовних одиниць, наприклад, питомі (Traum) і запозичені.

У семантичній структурі одержаних асоціатів на слово-стимул Überraschung виділяються три різновиди сем: 1) позитивні (35 чи 43,75\%), наприклад, Freude (25); 2) нейтральні (35 чи 43,75\%), наприклад, Welt; 3) негативні (7 чи 8,75\%), наприклад, Verachtung. Домінування в семантичній структурі одержаних асоціатів позитивних i нейтральних сем може вказувати на значущість і місце позитивних $\mathrm{i}$ нейтральних емоцій у житті досліджуваних, осмислення позитивних i нейтральних функціональних характеристик об'єкта розуміння (Überraschung), тенденцію до паралельного способу інтерпретації дійсності й тенденцію до переоцінки цінностей, що здійснилася на початку XXI століття як в емоційній сфері етносу, так і у вербальному іiі осмисленні, також мінливість інтересів, умотивованих бездуховною діяльністю чи кризу прояву позитивних емоцій. 
Наше спостереження над семантичним аспектом одержаних асоціатів показує, що емоційний стан подиву загалом пов'язаний із формуванням знань про предмет дослідження, наприклад Überraschungseier Kinderschokolade, та емоційного досвіду, наприклад Gesichtsausdruck, Stress.

Вивчення індивідуальних проявів значення одержаних асоціатів виявило наявність імпліцитного культурного ідеалу й моральних преференцій подиву. Приміром, ̈̈̈berraschung актуалізується досліджуваними як позитивний емоційний стан (28 чи 35\%): а) радості (Freude (25), glücklich sein, Lachen); б) подиву (Erstaunen) і негативний емоційний стан (2 чи 2,5\%): а) страху (Schreck); б) презирства (Verachtung); предмет, який дарують комусь (на день народження чи 3 іншої нагоди), щоб потішити винуватця свята (20 чи 25\%) (Geburtstagsgeschenk, Geschenk (19); святкування 3 нагоди дня народження (3 чи 3,75\%) (Geburtstagsfeiern) чи інших подій (Party (2); міжособистісні взаємини людини за статевими ознаками (2 чи 2,5\%): a) сукупність чоловіків / жінок / чоловіків і жінок (Freunde) і б) жінка статі (Freundin); сукупність усіх форм матерії як цільності, єдності; частина певного (космічного) простору (2 чи 2,5\%) (Welt, Wirrwarr); кількість однорідних об' єктів (2 чи 2,5\%): а) молоді істоти (Kinder): б) трав' янисті рослини, верхня частина яких складається із маточки, тичинки й пелюсток навколо них, має різне забарвлення i запах (приємний, неприємний, нейтральний) (Blumen); пережита емоція страху $(1,25 \%)$ (Erschrecken); продукт зрілого організму деяких видів рептилій і птахів жіночої статі як репродуктивний матеріал $(1,25 \%)(E i)$; день року появи когось на світ після пологів (1,25\%) (Geburtstag); образи, що виникають під час сну (1,25\%) (Traum); фізіогноміка (1,25\%) (Gesichtsausdruck); рівень розвитку людського інтелекту $(1,25 \%)$ (Heimlichkeit); одна із фаз розвитку людини, тривалість якої сягає від іiі народження до статевої чи соціально-правової зрілості $(1,25 \%)$ (Kind); форма прояву якості емоційного стану радості (1,25\%) (Kinderfreude); нова інформація $(1,25 \%)$ (Neuigkeit); столиця сусідньої держави Німеччини $(1,25 \%)$ (Paris); парна інтелектуальна (спортивна) гра на дошці, поділеній на 64 світлі і темні поля між 16 білими і 16 чорними фігурами за встановленими для них правилами (1,25\%) (Schach); інтенсивність відчуття фізичного і / чи психічного страждання (1,25\%) (Schmerzhaftes); фізіологічний стан жінки, яка носить під серцем дитину $(1,25 \%)$ (Schwangerschaft); специфічна пристосувальна реакція людського організму у відповідь на дію несприятливих зовнішніх або внутрішніх факторів $(1,25 \%)$ (Stress); характеристика смаку кулінарних виробів 
$(1,25 \%)$ (Süßigkeit); широкий спектр кольорової гами (1,25\%) (bunt); нова значуща позитивна ознака об'єкта $(1,25 \%)$ (interessant); розмір органів зору (1,25\%) (große Augen); процесуальність із негативною оцінкою (1,25\%) (mag nicht); форма і зміст кондитерського виробу, що виробляється підприємством цілеспрямовано - для дітей $(1,25 \%)$ (Überraschungseier Kinderschokolade).

Велике розмаїття семантики розглядуваних асоціатів на словостимул Überraschung засвідчує «енциклопедичну» множинність знань про пізнавальні психічні процеси й стани, переживання, вказує на «багатоканальну семантичну мережу» зв'язків подиву зі значущими для досліджуваних предметами й явищами дійсності, динаміку у словесному відтворенні концептосфери поняття «Überraschung», що формально простежується в трьох, уже зазначених, лексико-семантичних гілках зі своїми семантичними мікрополями: субстантивній, ад'єктивній і вербальній, чий кількісний обсяг є досить контрастним: від 2 (ад'єктивна й вербальна гілки) до 72 (субстантивна гілка). Формально, їх якісний склад можна охарактеризувати як стереотипно-перехідно-індивідуальний, зорієнтований на трансформацію й модифікацію значення об’єкта САЕ.

Одержана семантика асоціатів на слово-стимул Überraschung веде до розуміння того, що певна універсальна система емоційних i культурних цінностей i пріоритетів справді існуе й що форми іï лінгвістичного здійснення залежать від історичних умов, духу доби, типу особи як реального носія мовної свідомості й культури, мотивації й моменту мовлення.

Стереотипами асоціацій на слово-стимул Überraschung є Freude (25) i Geschenk (19) - усього 44 реакції чи 55\%, різних - 36 чи $45 \%$. Домінування серед асоціатів Freude (25) релевантне позитивному емоційному досвіду й знанням досліджуваних про емоцію радості, відповідному ставленню до осмислюваного й пережитого. Усвідомити padicmь як задоволення, приємне, втіху - означає усвідомити іiі інтегральну позачасову соціально-психологічну норму, соціокультурні критерії. Padicmь є ядро слова-стимулу Überraschung, саме вона наділяє його змістом. К. Е. Ізард, досліджуючи характерні особливості подиву, наголошує, що «якщо попросити людину згадати ситуацію, в якій вона переживала подив, то вона напевно розповість про радісну або приємну подію» [3, с. 191]. Учений ототожнюе подив із механізмом адаптації до ефективної взаємодії з новою, неочікуваною подією і ії наслідками. Цей механізм, на його думку, спроможний змінити загальний емоційний фон людини, загальмувати активність іiі 
нервової системи, звільнити провідні нервові шляхи, підготувати останні до нової активності [3, с. 194-195].

3 деяким застереженням можна твердити, що Überraschung дає змогу людині регулювати власну духовну й душевну рівноваги, $\epsilon$ оптимальним способом існування особистості насамперед у соціумі. Жити в світі, де визнаються соціально-психологічні норми на основі культурних критеріїв означає давати комусь безкоштовно щось ціннісно-матеріальне, виявляти небайдуже ставлення (позитивне чи негативне, але не нейтральне) до того, кому дарують певну річ, штучно змінювати параметри «свого» й «чужого» просторів за елементарною формулою «втрата - одержання - набування» (Geschenk (19) [12, c. 456].

Подарунок дає змогу усвідомити певну дійсність як культуру, емоційний стан як переживання, ставлення як морально-етичну норму. Отже, у центрі психологічно реального значення слова Überraschung є гіпотетично дві різнорідні сили, що перебувають у постійному конфлікті, й водночас у контакті - природне, утілене емоційно-психічним станом людини, а саме Freude (25), й штучне, цілеспрямований матеріальний витвір людського розуму й рук Geschenk (19). Тут Freude (25) - це так звана «істинна», а Geschenk (19) - так зване «переконливе» ставлення. Власне, Freude (25) є одна із найпотужніших частин емоційної сфери особистості, Geschenk (19) одна із креативних частин раціонального й прикладного. Гадаємо, Überraschung дає можливість і Freude (25), і Geschenk (19) ототожнити себе 3 емоційно-психічним i емоційно-фізичним загалом, стати підгрунтям емоційного.

Таким чином, вивчення семантики асоціатів на емотивноасоціативні слова сприяє глибшому розумінню емоційного досвіду, культури, моральних імперативів етносу. Тому важливим є подальше дослідження семантики асоціатів на ці й інші семантичні підкласи слів.

\section{Література}

1. Балашова С. С. Лінгвокультурний концепт як одиниця дослідження / С. С. Балашова // Сучасні дослідження з іноземної філології: зб. наук. праць / відп. ред. М. П. Фабіан. - Ужгород : ПП Підголіцин П. Ю., 2006. - Вип. 4. - С. 332-340.

2. Засєкіна Л. В. Психолінгвістична діагностика: навч. посібник / Л. В. Засєкіна, С. В. Засєкін. - Луцьк : Вежа, 2008. - 188 с.

3. Изард К. Э. Психология эмоций / Кэррол Эллис Изард ; [пер. с англ. В. Мисник, А. Татлыбаева]. - СПб. : Питер, 2008. - 464 с.

4. Максименко С. Д. Загальна психологія : навч. посібник [для студ. вищ. навч. закл.] / Максименко С. Д. - [2-е вид., перероб. та доп.]. - К. : ЦНЛ, 2004. - 272 с.

5. Мартинович Г. А. Опыт комплексного исследования данных ассоциативного 
эксперимента / Г. А. Мартинович // Вопросы психологии. - 1993. - № 2. - С. 93-99.

6. Минский М. Фреймы для представления знаний / Минский М. ; [пер. с англ. О. Н. Гринбаума]. - М. : Энергия, 1979. - 151 с.

7. Миронова Н. И. Ассоциативный експеримент: методы анализа данных и анализ на основе универсальной схемы / Н. И. Миронова // Вопросы психолингвистики. 2011. - № 2(14). - C. 108-119.

8.Селіванова О. Проблема комунікативного впливу в сучасному мовознавстві / Олена Селіванова // Мовознавчий вісник: зб. наук. праць / відп. ред. Г. І. Мартинова. Черкаси : Вид. ЧНУ ім. Б. Хмельницького, 2010. - Вип. 11. - С. 195-199.

9. Стернин И. А. Значение в языковом сознании: специфика описания // И. А. Стернин // Речевая деятельность. Языковое сознание. Общающиеся личности. XV Междунар. симпозиум по психолингвистике и теории коммуникации: тезисы докладов, 30 мая-2 июня 2006 г., Москва / ред. Е. Ф. Тарасов. - Калуга : Эйдос, 2006. - С. 290-292.

10. Терехова Д. І. Психологічний аспект зіставного вивчення лексичної семантики / Д. І. Терехова // Проблеми зіставної семантики : зб. наук. статей / відп. ред. О. О. Тараненко. - К. : Вид. центр КНЛУ, 2007. - Вип. 8. - С. 74-79.

11. Тропина Н. П. Семантическая деривация : мультипарадигмальное исследование : [монография] / Н. П. Тропина. - Херсон : Изд. ХГУ, 2003. - 336 с.

12. Langenscheidt Großwörterbuch Deutsch als Fremdsprache / [Hrsg. Götz D., Haensch G., Wellmann H.]. - Berlin : L., 2008. - 1307, [5] S.

Стаття надійшла до редакції 13.09.2012 p. 